\title{
National Poverty Eradication Programme and Poverty Reduction in Nigeria: Empirical Investigation of the Programme Impact in Cross River State
}

\author{
Antai, Agnes Sylvester \& Anam, Bassey Ekpenyong \\ Department of Economics \\ Institute of Public Policy and Administration \\ University of Calabar, Cross River State
}

Doi:10.5296/ijhrs.v4i3.5629 URL: http://dx.doi.org/10.5296/ijhrs.v4i3.5629

\begin{abstract}
The study examines the impact of the National Poverty Eradication Programme on poverty reduction in Cross River State. To guide the study, two major hypotheses were stated and primary data were obtained from 361 respondents from the benefactors of the State government Conditional Cash Transfer. The data obtained were tested using Chi-square statistical tool at. 05 degree of significance to examine the level of impact. The analysis of data in reveals that the calculated value of chi square (18.1) was greater than the table value of chi (9.49), tested at. 05 level of significance. This implied that the implementation of NAPEP has a significant impact on entrepreneurial development among youths in Cross River State. In table 2, the results obtained also showed that the calculated value of chi square (15.1) is greater than the table value of chi (9.49), tested at .05 level of significance, meaning that the null hypothesis was ignored and the alternative that the implementation of NAPEP has significant impacts on the provision of micro credit facilities to entrepreneur in Cross River State was accepted. However, the results obtained called for attention to other areas of interest neglected by the programme. These were identified to include the need to harness agriculture, water and solid minerals resources and conservation efforts especially in the rural-areas where the main occupation is agriculture. This concern formed the baseline for policy recommendations.
\end{abstract}

\section{Introduction}

Like most developing nations, several Nigerian governments have come up with policy measures to address the challenges of poverty reduction. One of such policy measures is the National Poverty Eradication Programme (NAPEP).The Government of President Olusegun Obasanjo, at inception in May, 1999, expressed deep concern about the rise of poverty in Nigeria. The Government realized that if the worsening poverty situation is not checked, the future of the nation would be doomed (Aku \& Oladeji, 1997). In light of this, the Government introduced a number of measures aimed at making a dent on poverty. Among other things, these measures were intended to restore hope to the masses. This involves providing basic necessities to hitherto neglected people particularly in the rural areas; restore 
economic independence and confidence; and foster wealth creation.

Notwithstanding its laudable objectives, the present incidence of poverty in the Cross River State, and Nigeria at large can lead to the conclusion that the past poverty alleviation programmes have not achieved much. Rural areas are still characterized by inadequate infrastructural facilities. Evidence is in the persistence of rural poverty, resulting from lack of access to education, health facilities, portable water, electricity, good roads and so on. The consequences are low literacy level and poor health standards due to undernourishment and diseases as well as low economic productivity (Aliu, 2001; Ogunmike, 2001 \& Bradshaw, 2006). This continuing trouble state necessitates this study. This is perhaps due certain local and institutional challenges hindering the effective implementation of these programmes.

One of the objectives and mandate of NAPEP is: the provision of employment and income generation through various activities. However, lack of involvement of the target beneficiaries in identifying the right projects coupled with administrative and operational failures are among the problems hindering the achievement of the objectives of the programmes. This study is set to examine the impact of rural development policies on the improvement of rural infrastructure in Cross River State.

\section{Statement of the problem}

The problems of rural Nigeria have been of concern to scholars and policy makers since the 60s. Ebong (1991) confirmed these concerns when he listed the challenges of rural Nigeria to include, lack of basic infrastructures; poor access roads; a dirge of educational facilities; lack of pipe borne water; inequality; low per capita income; high unemployment; and what have you. Esema (2007) added that they are usually characterized by poor health; lack of basic nutrition; inadequate housing; social discrimination and inadequate/ineffective channels through which concerns can be voiced. To transform the vast rural areas of Nigeria into the mainstream of national development, governments at various levels (federal, state and local) have come up with a number of policies and programmes. One of these policy measures is the National Poverty Eradication Programme, set up in 1999 by the Obasanjo administration (Anam, 2011).

In spite of the policy measure, the poverty level has remained unchanged, particularly in the rural areas. In Cross River State, investigation shows most rural communities lack basic social and economic amenities which, impact negatively on the well-being of the people. The study will investigate the impact of rural development policies on the socio-economic lives of the people, with specific attention to the National Poverty Eradication Programme policy framework, 2007-2009 in the State.

\section{Objectives of the study}

The study examines the impact of the NAPEP on poverty reduction in Cross River State. Specifically, the study seeks to achieve the following,

1. Examine the impact of the policy entrepreneurial development among youths in Cross River State.

2. Assess the impact of the policy on the provision of micro credit facilities to entrepreneur in Cross River State. 
3. Find out the major problems hindering the effective implementations of the objectives of the National Poverty Eradication Programme in Cross River State.

4. Provide strategies for the effective performance of the policy and the development of the state, especially the rural populace.

\section{Research hypotheses}

The study will be guided by two (2) basic assumptions. These are,

1. There is no significant effect between the implementation of the National Poverty Eradication Programme on entrepreneurial development among youths in Cross River State.

2. There is no significant effect between the implementation of the National Poverty Eradication Programme on the provision of micro credit facilities to entrepreneur in Cross River State.

\section{Methodology}

The study adopts a descriptive design approach. Descriptive design is aimed at obtaining data concerning the current status of phenomena. Data are obtained from primary and secondary sources. Benefactor of the State government Conditional Cash Transfer (CCT) constitute the sample population used for obtaining primary data in testing the hypotheses stated in the study.

\section{Literature review and theoretical framework}

Poverty reduction has remained a key issue dominant development challenge facing most developing nations of the world. Social Sciences literature is replete with attempt by Economists and other Social Scientists' to conceptualize the phenomenon. Poverty has economic, social and political ramifications. The poor are materially deprived, socially alienated and politically excommunicated. Poverty as lack of access to basic needs/goods is essentially economic or consumption oriented. Thus the poor are conceived as those individuals or households in a particular society, incapable of purchasing a specified basket of basic goods and services. Basic goods as used here include; food, shelter, water, health care, access to productive resources including education, working skill and tools, political and civil rights to participate in decisions concerning socio-economic conditions (Ajakaive and Adeyeye 2001 in Gbosi ${ }_{\mathrm{r}}$ 2004). It is generally agreed that $\mathrm{m}$ conceptualizing poverty, low income or low consumption is a defining characteristic.

Between 1980 and 1992, the average poverty incidence in Nigeria increased from 0.28 to 0.43 respectively. By 1996, the situation had worsened to an average of 0.66 , (which implied at.the time that, out of every 100 Nigerians, 66 were living below the $\bullet$ poverty line) (Putman, 2000). This increasing level of poverty in the Country was despite all the efforts implemented by all the Ministries and Agencies established by Government to fight poverty. Some of the reasons for the low impact or total failure of these structures include:

Poor coordination of activities and absence of effective continuous policy formulation;

1. Lack of sustainability of programme and projects; Absence of achievable target setting;

2. Absence of monitoring, evaluation and impact assessment; 
3. Absence of effective coordination, collaboration and complementation between the agencies and among the three tiers of Governments; and

4. Duplication of functions with a resulting unnecessary rivalry among institutions.

The above problems set the agenda for concern on a more improved modality to streamline and rationalize the functions of core poverty alleviation institutions and agencies; reduce overlapping functions; enhance their effective performance; improve coordination; and improve collaboration with State Governments, Local Governments and International Donor Agencies. In addressing these daunting challenges, the government in 2001, established the National Poverty Eradication Programme. The programme was aimed at the provision of "strategies for the eradication of absolute poverty in Nigeria" (FRN, 2001). 11 was complemented by the National Poverty Eradication Council (NAPEC) which was to coordinate the poverty reduction related activities of all the relevant Ministries, Parastatals and Agencies. The council had the mandate to ensure that the wide range of activities were centrally planned, coordinated and complement one another so that the objectives of policy continuity and sustainability were achieved. The xnvrn reduction related activities of the relevant institutions under NAPEP have been classified into four, namely;

1. Youth Empowerment Scheme (YES) which deals with capacity acquisition, mandatory attachment, productivity improvement, credit delivery, technology and development and enterprise promotion.

2. Rural Infrastructure Development Scheme (RIDS) which deals with the provision of potable and irrigation water, transport (rural and urban), rural energy and power support

3. Social Welfare Service Scheme (SOWESS) which deals with special education, primary healthcare services, establishment and maintenance of recreational centres, public awareness facilities, youth and students hostels development, environmental protection facilities, food security provisions, micro and macro credits delivery, rural telecommunications facilities, provision of mass transit, and maintenance culture.

4. Natural Resource Development and Conservation Scheme (NRDCS) which deals with harnessing of agricultural, water, solid mineral resources, conservation of land and space particularly for convenient and effective utilization by small scale operators and the immediate community. NAPEP is funded by the Poverty Eradication Fund (PEF). PEF is administered by the National Poverty Eradication Council. NAPEP is also funded from contributions given to it by state and local governments, the private sector and special deductions from the Consolidated Fund of the Federal Government. It also gets donations from international donor agencies such as the World Bank, the United Nations Development Programme, the European Union, the Department for International Development, the Japanese International Cooperation Agency, and the German Technical Assistance. At inception in 2001, it was given a takeoff grant of N6 billion. This money was used to establish NAPEP structures in 36 states, the Federal Capital Territory, Abuja and 744 local government councils. Part of the money was also used in the NAPEP employment generation intervention which translated to the training of 100,000 youths, attaching 50,000 unemployed graduates in various places of 
work, training of over 5000 people in tailoring and fashion design, and the establishment of rural telephone networks in 125 local government areas.

Other uses to which the money was put include the delivery of the KEKE-NAPEP three-wheeler vehicle project involving 2000 units in all the state capitals of Nigeria, the establishment of 147 youth information centres across the senatorial districts, the delivery of informal micro credit ranging from N10, 000 to N50, 000 to 10,000 beneficiaries most of whom were women, and so on (Anam, 2011).

The Cross River State government is commended for initiating the Conditional Cash Transfer, as a means of enhancing the entrepreneurial capacity of citizens in the State. The programme (CCT) was designed by NAPEP after a rigorous research process, and is now being adopted by states as was the original plan; in line with state-community ownership of poverty eradication. The Free Health Care for pregnant women and children and the scaling-up of -the Conditional Cash Transfer programme in Cross River State are two great poverty eradication initiatives that have the potential to change the lives of the poor. The government hopes that the programme will have strong potentials to break the inter-generational transfer of poverty and help states achieve their poverty eradication targets. The strategy has always been to catalytically intervene to build a 'can do spirit' among states and local governments. The government of Cross River state has, with this launch, demonstrated that with good understanding and effective partnership, states and local governments can mobilize resources to support the former President's vision of poverty eradication in the country. The programme has made tremendous contributions in achieving its fundamental objectives in the state.

In more recent development, Kunle (2008) disclosed that the National Poverty Eradication Programme (NAPEP) in Cross River State says it has disbursed a total of N121, 662,062 to about seven micro finance banks for onward disbursement to 101 cooperative societies across the 18 local councils of the state. The money was disbursed under the NAPEP's Village Economic Development Solution programme, which is a local community-driven development programme. Under the programme, a community is expected to form cooperatives and thereafter is allowed to choose a project where it has comparative advantage while NAPEP will assist with the funding of the project through the cooperative(s). Kunle (2008) cited Willy Samuel Eno, Coordinator of NAPEP in the State, on the position that 101 benefiting cooperative societies were selected from a list of 786 who sent business plans to that effect. The business plans were screened by a joint implementation committee made up of stakeholders in the poverty eradication programme who short listed to benefiting 101 cooperatives spread across the 18 local councils of the state. Eno maintained that 35 projects were selected under the anchor project of the programme while 66 were from the capacity widening activities. He explained that anchor projects have to do with such projects as the establishment of a cassava mill, while the capacity widening activities involved dealing with the farmers who would provide feedstock for the mill (in Kunle, 2008).

Under the anchor project, a cooperative gets at least N2 million while under the capacity widening activities, a cooperative gets at least $\mathrm{Nl}$ million adding that the total amount a cooperative gets eventually was dependent on the number of co-operators it has. Fie gave the list of the seven micro finance banks involved in the disbursement as: Ekondo Micro Finance Bank, Bakassi Micro Finance Bank and Calabar Micro Finance Bank. Others, he said are 
Central Senatorial District Micro Finance Bank, Ogoja Micro Finance Bank, Obudu Urban Micro Finance Bank and Utugwang Micro Finance Bank. The coordinator said that with the latest disbursement, NAPEP had spent a total of N281.5 million in all its programmes in the state in the past three years (Kunle, 2008).

Under the Conditional Cash Transfer targeted at the vulnerable group in the society NAPEP has spent N72 million on 500 beneficiaries in 10 local councils of the state, N122 million under the Village Economic Development Solution, N65 million on Multi Finance, N17.5 million under Repackaged CAP and N4.5 million on the Farmers Empowerment Programme. Fie also used the opportunity to thank the state governor for his support to the activities of NAPEP in the state saying that he has been very supportive to the programme. Eno said the governor had pledged N192 million supports to the Conditional Cash Transfer and Village Economic Development Solution of the programme adding that the amount has been factored into the supplementary budget of the state (Kunle, 2008). Today, Cross River State is cutting new grounds by integrating biometric data capture for added efficacy of the programme.

- At the federal level, the Committee on National Planning, Economic Affairs and Poverty Alleviation has approved N1.6biilion budget for the National Poverty Eradication Programme (NAPEP), its Chairman, Senator Barnabas Gemade, has said. Gemade, who spoke at the agency's 2013 budget defence in Abuja, assured NAPEP of its willingness to support its well-meaning people oriented programme. Fie said: "The Committee was concerned about the plight of poor Nigerians who voted ti i have their condition of life improved, but unfortunately much is still being expected from government after coming this far. He noted further that poverty alleviation programmes should not be subjected to undue delays arising from prolonged procurement processes, which means the funds mean; for the poor people should be effectively and speedily delivered.

The Senior Special Assistant to the President and National Coordinator, NAPEP, Malam Mukhtar Abubakar Tafawa Balewa said the agency met its target by concluding 100 per cent payment in respect of Conditional Cash Transfer Scheme under the 2012 budget provision. The Committee urged NAPEP to present a supplementary budget estimates to reflect the recent reviewed allocation to the Programme. This has been significant in improving the economic conditions and lives, of Nigerians, especially the rural poor that are most vulnerable to unhealthy social and economic conditions.

\section{Theoretical framework}

There are several theories which attempt to explain the challenges of poverty reduction and economic development. However, within the context of this study two theoretical positions are examined. 


\section{Macrothink Institute ${ }^{\mathrm{TM}}$

\section{i. Integrated rural development approach}

Hallet (1996) is the proponent of the integrated rural development approach. He maintained that development is concerned with everyday things, including the crops sown by the farmer, the goods sold and the road along which it is transported to the market by the trader, the school attended by children and the disease affecting a baby. The integrated rural development approach, therefore seeks to understand these linkages and to make appropriate provisions for the resultant effects of alteration in one or a few elements on the others.

The approach considers development to be a comprehensive and holistic strategy, involving the improvement of the entire rural economy. Also, the strategy emphasizes the fact that the economic base in the rural areas has to broadened through efforts to mobilize and better utilize human and natural resources by providing services: by creating motivation and purchasing power through better distribution of income and employment opportunities: by establishing-closer links between the agricultural, industrial and service sector in the rural areas; and by improving the conditions of living regarding housing, water supply, roads, etc., through assistance to self-help actions.

This approach appears to be holistic in explaining the peculiar rural needs examined in this study; water supply, roads and educational facilities. It advocates that developmental strategy must be multidimensional, covering improved provision of services, enhanced opportunities for income generation through opening access roads, improving physical infrastructure, especially, educational infrastructures, improving the health status of the rural population through access to portable water and other institutional framework necessary to improve rural lives. Rural capacity development in this context is thus much broader than poverty alleviation, the focus is on facilitating change in rural environments to help the rural vulnerable improve their capacity, to earn more, invest in themselves and their communities, contribute toward maintenance of the infrastructure key to their livelihoods; in short, to identify opportunities and to act on them.

\section{ii. The participatory approach}

With the inconsistencies observed in rural development models, the participatory approach or model is seen as an alternative approach to help explain and address the problems of rural areas in Nigeria. Advanced in the works of Fiorino and Bowles (2001), the approach is a comprehensive and well strategized activity requiring the role of rural dwellers. Participation must start from the planning stage; at planning or project initiation, the people for which the project is planned for must be the drivers and part of the decision making process, to help identify areas of felt needs. Equally, proper human training (i.e. the rural dwellers) must be completed; especially in technical areas were such skills will be required in project implementation and maintenance. Ering (2000) argued that the failure of the "top-down" development approach to rural development necessitates "the participatory model" to socioeconomic development. The model emphasizes -the participation of the beneficiaries and the role of communities as major actors" It is a model that involves "putting the last first" or the "farmer first" (Ering, 2000), and is fundamental to', the entire development process which is linked with poverty alleviation' and rural development. The approach or model focuses on sustainable quality of life; and attempts to put people rather than materials/funds at the centre 
of development.

Equally, the model advocates for a support system, ensuring that rural dwellers get involved, accept and support rural projects. Individual participation in rural development initiatives is generally supported for its potential to provide low-cost sources materials like sand, water, timbers, gravels, and other local resources to government agencies. This increases acceptance of projects and confidence in government decisions (Miller, 2000). There is therefore need to achieve a balance in both policies and strategies directed at poverty reduction and rural development. Granted a comprehensive approach with rural participation, the objective of improving rural lives can be objectively attained.

The contention is that the development of rural Nigeria should be a function of the "rural man" themselves that have to take their destinies in their hands in order to improve their socio-economic conditions (Ering, 2000). The policies and programmes for rural development must elicit the participation of the people whom the policies and programme arc plan for. In other words development must be "woven around people, not people around development. The participatory model is dynamic in the sense that it makes the local rural people to control the economic, social, political and cultural processes that affect their lives. It provides better understanding of community problems and new solutions. Hence, it's the key to, the learning process and capacity building, and that people's empowerment is, a process of sustainable human development.

\section{Data presentation and analysis}

To obtain primary data for the study, a structured research questionnaire was developed and administered to 361 respondents in the state capital. All the respondents were benefactors of the Conditional Cash Transfer. Data obtained were tested using Chi-square statistical analysis.

Hypothesis 1: The implementation of NAPEP has no significant impact on entrepreneurial development among youths in Cross River State. Table 1 Chi square (X2) response to examine the impact of NAPEP on entrepreneurial development among youths in Cross River State

\begin{tabular}{|l|l|l|l|l|l|l|}
\hline Variables & SA & A & D . & SD & UD & \\
\hline $\begin{array}{l}\text { the implementation of the } \\
\text { National Poverty Eradication } \\
\text { Programme }\end{array}$ & $90(89.9)$ & $52(63.2)$ & $71170.8)$ & $62(51.0)$ & $0(0)$ & 275 \\
\hline $\begin{array}{l}\text { Entrepreneurial development } \\
\text { among youths in Cross River } \\
\text { State }\end{array}$ & $28(28.1)$ & $31(19.8)$ & $22(22.2)$ & $5(15.9)$ & $0(0)$ & 86 \\
\hline & 118 & 83 & 93 & 67 & 0 & .361 \\
\hline
\end{tabular}

Cal X2 18.1 Table value of Chi 9.49; Level of significance .05; df, 3 Key and decision rule: In each column, there are two levels of responses; the one outside the bracket is the Observed Frequencies, while the Expected Frequencies are bracketed. Reject the null hypothesis and accept the alternative, when the calculated value of Chi-square is greater than the table value of Chi square 


\section{Decision and interpretation of results}

The analysis of data in Table 1 above reveals that the calculated value of chi square (18.1) was greater than the table value of chi (9.49), tested at .05 level of significance. This implies that the null hypothesis, that the implementation of NAPEP has no significant impact on entrepreneurial development among youths in Cross River State is rejected and the alternative accepted. This implies that the implementation of NAPEP has a significant impact on entrepreneurial development among youths in Cross River State.

Hypothesis 2: The implementation of NAPEP has no significant impact on the provision of micro credit facilities to entrepreneur in Cross River State.

Table 2 Chi square (X2) response to examine the impact of NAPEP on the provision of micro credit facilities to entrepreneurs in Cross River State

\begin{tabular}{|l|l|l|l|l|l|l|}
\hline Variables & SA & A & 0 & SD & UD & \\
\hline $\begin{array}{l}\text { the implementation of the National } \\
\text { Poverty Eradication Programme }\end{array}$ & $87(90.9)$ & $91(91.0)$ & $68(70.5)$ & $76(72.2)$ & $0(0)$ & 322 \\
\hline $\begin{array}{l}\text { the provision of micro credit facilities } \\
\text { to entrepreneurs in Cross River Stats }\end{array}$ & $15(11.0)$ & $810.7)$ & $11(8.5)$ & $5(8.8)$ & $0(0)$ & 39 \\
\hline & 102 & 99 & 79 & 81 & 0 & 361 \\
\hline
\end{tabular}

CalX2 15.1 Table value of Chi 9.49; Level of significance .05;df3

\section{Key and decision rule:}

In each column, there are two levels of responses; the one outside the bracket is the Observed Frequencies, while the Expected Frequencies are bracketed. Reject the null hypothesis and accept the alternative, when the calculated value of Chi-square is greater than the table value of Chi square Decision and interpretation of results

In Table 2, the result obtained in the analysis reveal that the calculated value of chi square (15.1) is greater than the table value of chi (9.49), tested at .05 level of significance. By implication, the null hypothesis is ignored and the alternative accepted, meaning that the implementation of NAPEP' has significant impacts-on the provision of micro credit facilities to entrepreneur in Cross River State.

\section{Implication of result and research gap}

From the results obtained from the analysis of primary data above, the two hypotheses shows that the implementation of NAPEP has significant impacts on entrepreneurial development among youths and the provision of micro credit facilities to entrepreneur in Cross River State. Notwithstanding, much is still to be desired. The findings agrees with the earlier position of Mustapha (2012) that there is emphasis on the youth empowerment scheme (YES) neglecting the other mandates; even the YES itself focused more on the disbursement and administration of NAPEP's vehicle popularly called "KEKE NAPEP". To explain the significant level obtained in the results above. Issues of natural resource development and conservation scheme, Abdu (2012) observed, from a cross national assessment, less than $20 \%$ of the target beneficiaries have benefited through this scheme. This means that NAPEP has not made 
much impact in harnessing agricultural, water and solid minerals resources and conservation efforts especially in the rural areas where the main occupation is agriculture. There is also more concern in the development of educational and health facilities in rural communities in the state.

\section{Conclusion}

Like other attempts to improve the lives of citizens, NAPEP as a policy direction towards poverty reduction has had its own share of contribution in improving the social and economic status of Cross riverians. Cross River State as one of the 36 states in the Nigerian federation, and one of the six states in the South-South geo-political zone has not been insulated from the various efforts at poverty reduction. Though successive governments in the state have tried to address the issue of poverty as captured above, the effect of the policies and programmes on reducing poverty among the populace has been that of mixed feelings. The questions bothering a great number of the citizens are:

1. With concerted efforts at poverty reduction in the state, why is poverty on the increase?

2. What is the effect of the increasing poverty rate on the economy of the state, and the nation at large?

3. Are there better ways or strategies of implementing poverty reduction programmes to make them more effective? These questions may provide the platform for policy recommendations and further research within the purview of this assessment.

\section{Recommendations}

In the light of the above questions and policy concerns, the following recommendations are advanced,

1. Poverty reduction strategies should be implemented within a holistic and integrated framework. At present there is a segmented propriety in programme implementation, particularly to Youth Empowerment Scheme (YES) neglecting the other mandates. Poverty is a multi dimensional phenomenon and should be address as such for meaningful impact.

2. There is need to strengthen the capacity of NAPEP through improved budgetary allocation. Other stakeholders; federal, state, local and institutions concerned with poverty reduction should increase concern so that other objectives/ projects identified by the agency can be address.

3. There is further need to sustain poverty reduction strategies, especially in the provision of employment. After skills acquisitions opportunities should be provided to engage the trainee on jobs. Funds should also be made available to enable trainee set up small and medium scale business.

4. There is need for an institutional mechanism to monitor progress in policy implementation. This will enhance changes were necessary for effective policy implementation.

5. Equally, there is the need for the government to supply necessary inputs that can improve people's livelihood, productivity and increase their level of income. These 
inputs can be in form of fertilizers, farming machines, seeds, training programmes, skill acquisition programmes, credit facilities and others (Mustapha, 2011).

6. The government's anti-corruption efforts should be proactive in dealing with matters concerning poverty reduction programmes/ agencies and even beneficiaries.

7. A stable macro-economic policy formulation, stable tax and fiscal policy and proper implementation are basic to government for effective poverty reduction efforts.

Good governance, sustainability of policies and programmes and good leadership are also significant in addressing poverty reduction in the country. Effective mobilization of citizens through campaigns, publicity, talks and seminars to advance popular support and to change the attitudinal disposition of the poor towards government programmes, employment and empowerment drives, is sin qua non for poverty reduction especially among rural communities in Nigeria.

\section{REFERENCES}

Abdu, H. (2012), "Impact of National Poverty Eradication Programme (NAPEP) on Income Changes in Rural Areas" Unpublished seminar paper, Abuja.

Ajaikaye, D.\& Adeyeye, V.(2001), "Concepts, Measurements and Causes of P

Aku PS \& Oladeji, S.I (1997), "Perspective on Poverty and Poverty Alleviation Strategies in Nigeria" NES Annual Conference.

Aliu, A. (2001), "National Poverty Eradicate Coordination and Monitoring" NAPEP Abuja.

Anam, B. (2011), "Understanding Rural Development". Calabar Kings view Publishers.

Bradshaw, T.K. (2006), "Theories of poverty and Anti- Poverty Programs in Community Development" http//:www.rprconline.org/ , M. (1991). "Mobilization of resources for rural development in Nigeria". Calabar: Wusen Press.

Erring, S. O. (2000). Nigerian rural development policies and social engineering: Issues of theory and practice. Journal of Agribusiness and Rural Development, 1 (1), 21-23.

Esema, M. B. (2007). "Improving youth livelihood: SSA Report of the International Development Center". Lagos: Drumlin Publishers.

Federal Republic of Nigeria. (2001). A Blueprint for the Schema of National Poverty Eradication Program (NAPEP), Abuja

Fiorino, G. \& Bowels, H. (2001). "Industrialization and the rural poor". London: Macmillan.

Hallet, G. (1996). Development policy in sub-Saharan Africa after 15 years of structural adjustment. American Rural Development Review, 4 (2), 22-24.

Kunle, J. (2008) The Nation newspaper.NAPEP disburses N122m to 101 cooperatives in Cross River State

Mustapha, M. (2011) Poverty alleviation as a machinery for economic re-construction in Nigeria.

http://mustaphamuktar.blogspot.com/2011/01/poverty-alleviation-as-machinery-for.ht $\mathrm{ml}$

Ogwumike, F.O. (2001), "An appraisal of Poverty and Poverty Reduction Strategies in Nigeria" CBN Economic and Financial Review Vol. 39 No. 4

Putman, R.D. (2000), Bowling Alone. New York: Simon Schuster. 